\title{
Impact of the Language of instruction on Writing Competence of Learners in Zimbabwean secondary Schools: A case of Gweru Region
}

\author{
Dube Precious and Gumbo Lettiah
}

Midlands State University, Communication Skills Department, Private Bag 9055, Gweru, Zimbabwe

\begin{abstract}
This study seeks to analyse how language of instruction affects writing competence of learners in selected schools in Zimbabwe. Competence according to Chomsky (1965) refers to, the native speaker's knowledge of the language, that is, knowing the rules of the language. Writing competence therefore includes, a set of different abilities which are necessary for composing good texts. This study will look at the writing competence of learners in Zimbabwe, since writing can be seen as a process for which suitable work techniques must be available. This study used the qualitative approach with a sample of secondary school teachers, from both public schools and private schools, secondary school learners from form four (4) classes, from both public schools and private schools, parents, and government officials who are in charge of these schools. Questionnaires and interviews and documentary review were used as research instruments for this study. This study concludes that language of instruction has a major influence on learners' academic achievement. While most teachers have a good command in the language of instruction, they have to use coping strategies such as code-switching and translation to help students understand the lesson properly.
\end{abstract}

Keywords- Writing competence, translation, translanguaging, code switching; bilingualism, multilingualism, proficiency.

\section{INTRODUCTION}

The interest of doing a research on how the language of instruction affects writing competence and performance in Zimbabwean secondary schools is because of personal experience of teaching in both high density public secondary schools and in private schools in Zimbabwe. In our experience as secondary school teachers, we realised that, in high density secondary schools, the ability of students to use the language of instruction which is English, in class is very minimal. Some of the learners struggle to express their ideas clearly in academic writings because they have not yet attained adequate proficiency levels that would enable them to write efficiently in the English language. This hinders them from performing well in their day today written work especially in their examinations. To the students, English is a classroom language because it is only used meagrely in the classroom. Students in private schools, who use English for their day to day communication, in and outside the classroom also face problems when it comes to writing. They seem to be very good in speaking the language but have challenges when it comes to writing. This shows that, academic writing requires a conscious effort and much practice in composing and developing ideas. Myles (2002) supports this saying, "the ability to write well is not a naturally acquired skill. It is usually learned and or culturally transmitted as a set of practices in formal instructional settings or other environments." Hence speaking fluently in the language does not automatically mean that, one can efficiently write in the language.

The researchers have observed that, public and private schools, differ in terms of the extent to which, the Language of instruction influences their academic performance. This is so because teachers in public schools do not emphasise on the use of the English language even in the classroom, unlike their counterparts in private schools who have to communicate in English language always in and outside the 
classroom and teachers have to enforce this in their learners. Therefore, the proposed study aims to analyse how the language of instruction in Zimbabwe in this case English, affects writing competence of high school learners in both high density public schools and private schools. Specifically, it seeks to assess, how the language which is used by teachers to deliver their lessons, in Zimbabwean secondary public and private schools, particularly in the Midlands region, affects students' competence and performance in writing, an area which is still grey so far.

Most pupils in Zimbabwe, especially in the Midlands region, in both public and private secondary schools have poor writing skills. Their ability to use English, which is the official language of instruction in class especially when writing, is very minimal. Some of the learners struggle to express their ideas clearly in academic writings because they have insufficient linguistic proficiency, which hinders them from performing well at school since English is the official medium of instruction. This research will assess their writing competence.A lot of research has been done on the effect of the medium of instruction on the leaners academic performance in general, but only a few studies have focused on the effect of the language of instruction on the writing skill and non that is known, has focused on the effect of the language of instruction on writing competence in Zimbabwean public and private schools, which is the main focus of this research. The research will also look at the similarities and differences that can be drawn from the two schools in terms of language of instruction and its impact on competence. Using translanguaging and Critical Discourse Analysis theories, the study seeks to clarify how the language of instruction affects writing competence in private and public schools in Zimbabwe especially in the Midlands region in Gweru. The study focuses on the analysis of pupils' written documents in order to assess their competence in writing.

Language of instruction (LOI) is the language used for the purpose of imparting knowledge in education system and normally selected by the government of the country to meet the demands of the dynamics of knowledge growth and expansion (Mkude, 1999 in Komba and Bosco 2015).Language of instruction plays a significant role in students' academic performance (Kagwesage, 2012) and a good number of studies have been conducted worldwide on this topic.Mlay (2010) conducted a study on the influence of the language of instruction on students' academic performance in secondary schools in Tanzania. The main objective of the study was to examine the impact of the language of instruction on urban and rural students' academic performance in the subjects of History and English language. The findings indicated that students in urban secondary schools performed better than students in the rural schools because of better English language exposure. This study however is looking at how language of instruction affects writing competence in secondary schools in Zimbabwe.

Komba et al., (2012) cited in Komba and Bosco (2015) conducted a study which sought to compare students' abilities in written English language skills and their academic performance in Tanzania. The main objective of this study was to find out whether or not there was a correlation between students' abilities in written English language skills and their academic performance. The findings indicated that there was a significant positive relationship between the students' abilities in the English Writing Skills Test (EWST) and their academic performance.Brock-Utne (2004) has also carried out some studies in Tanzania, a country that also chose English as an official language. She actually finds the English policy in the country quite problematic, especially when considering the language context in the country. This study however sought to look at how the language which is used for teaching and learning affects the writing competence of learners.

Writing has been identified as one of the most essential skill that students require for their personal development and academic success because the world has become so textoriented (Cole and Feng2015). Similarly, Rao (2007) points out that, writing strengthens students' learning, thinking and reflecting on the English language in their academics. Ahmed (2010) has also noted that, competence in writing helps students perform well in their academic programs. Moreover, being proficient in writing in English will enable students to be professionals and action researchers in the future. However, it has been noted that, learning to master writing skills is a problem students face at all levels of the education system. Ong'ondo (2001) notes that, writing skills are of major importance to students at all levels of the education system. This is because most examinations and assignments learners do at schools are mainly assessed through writing. It is probably because of this crucial role in assessment that writing has been considered the most important skill that students require for their academic advancement. This implies that, learners should be helped to 
acquire skills that will enable them to express their ideas clearly and effectively in writing.

Kroll (2003) notes that, improving the writing abilities of students has both academic and social implications. He observes that, helping students to write clearly, logically and coherently about ideas, knowledge and views will expand their access to higher education and give them an opportunity for advancement in the work force. He further observes that the current trends of globalization and internet revolution have come to require proficiency in English language that goes beyond the spoken language, thus embracing a variety of uses of the written language. Among such uses include; writing of business letters, memos and telephone messages. This further underscores the importance of learning writing skills. However, there has been a considerable concern that majority of the students do not develop the competence in writing they need to be successful in school, workplace, or their personal lives (Graham and Perin, 2007). It is against this observation that this study will analyse writing skills of learners in Zimbabwe at secondary school level and it is hoped that the recommendations from this study will serve as a basis of improving the learning of writing skills among students.

Writing in a second language seems to be the most difficult skill for language learners to acquire in the academic context (Negari, 2011). Myles (2002) argues that various social and cognitive factors help in assessing the underlying reasons why second language (L2) learners exhibit particular writing errors. According to Myles (2002), social factors that influence second language writing include motivation and attitudes. Similarly, Ellis (2003) argues that social factors explain why learners differ in the rate of L2 learning and in proficiency type, for instance, conversational versus writing ability. Research based on motivation and attitudes shows that, learners with positive attitudes and motivation towards writing for academic purposes experience success unlike those with negative attitudes (McGroarty 1996).

Numerous factors that affect students' writing skills have been identified in literature. These are associated with the motivation of learners who are generally unclear about the purpose and significance of their text in their L2 learning. Similarly, social media, inconsistent feedback from teachers, learners' lack of analytical and evaluative approach, and large and unmanageable class sizes also negatively impact the structural and communicative accuracy of the students' texts (Pineteh 2013). Most of the students find it very challenging to obtain sufficient and relevant source information, paraphrase or summarize information, and use an appropriate academic writing style (Gonye et al2012). It is caused by delayed essay writing instruction, large classes, students' negative attitude towards their academic English course, first language(L1) transfer, and lack of dialogue between students and teachers about the constructive steps that need to be taken to address these problems. In Pakistan, insufficient time for teaching writing, improper $\mathrm{A} / \mathrm{V}$ aids, overcrowded classrooms, traditional pedagogy and students' weak academic backgrounds have been reported to be some of the factors affecting students' writing skills (Bilal et al., 2013). Similarly, outdated textbooks that neither promote the importance of a writing skill, nor give any opportunities, too consequently fail to invoke an audience (Haider,2012). Another body of research critiques incompetent teachers who instead of promoting creative skills urge students for rote learning and exam-oriented language production (Rahman,2002; Siddiqui, 2007).

(Graham \& Perin,2007) have noted that students' writing ability can be improved by fostering their interest, motivation and enjoyment for writing, through technology). Similarly, some metacognitive, cognitive and socio-affective strategies could also be used for enabling the students to know and practically exercise the writing process (O'Malley \& Chamot, 1990). Further, the teachers can adapt their pedagogic approaches and can mutually design such tasks that could motivate and encourage students by giving them liberty of choosing topics of their interest (Pineteh,2013;Quintero,2008).Thus the current study would like to analyse writing competence of learners in Zimbabwean selected secondary public and private schools, an area which is still grey in the field of linguistics.

Educators might gain new insights that will help to determine the best way to implement classroom-language policy. Likewise, light is likely to be shed on effective English teaching and learning in different ESL contexts. It may also help educators in the field of linguistics on the knowledge that can be tapped from language policy matters in Zimbabwe. This research might be of great significance to the academic field as it may help aspiring researchers who may find it valuable in establishing literature for the purposes of review. It may also expose policy makers and linguists on the role and importance of language policy in Zimbabwe. The results of this research might be very important as input on language policy and planning in Zimbabwe. It is also anticipated to be an eye opener during language debate forums in Zimbabwe. 
The theoretical framework for this study is based on the Critical Discourse Analysis, (Fairclough 1995, van Dijk 2001 and Wodak 2001) and The Translanguaging Theory Colin Williams (1994) and developed by García (2009). The frameworks are suitable for this study as they identify linguistic structures in discourse.

\section{Translanguaging Theory}

According to Garcia (2009), translanguaging is the act performed by bilinguals of accessing different linguistic features or various modes of what are described as autonomous languages, in order to maximize communicative potential.The term was originally used by Colin Williams in 1994. It was later popularized by Garcia (2009); Creese and Blackledge (2010); Canagarajah (2011); Garcia and Sylvan (2011) and Garcia and Wei (2014) where it was put in the context of second language learning in bilingual and multilingual contexts seeking to assist multilingual speakers in making meaning, shaping experiences, and gaining deeper understandings and knowledge of the languages in use and even of the content that is being taught (Cenoz \& Gorter, 2011; Lewis etal 2012).

According to Canagarajah (2011), translanguaging is the ability of multilingual speakers to alternate between languages, treating the different languages that form their repertoire as integrated system. García (2009) extended the scope of translanguagingto refer to processes that involve multiple discursive practices, where students incorporate the language practices of school into their own linguistic repertoire freely and flexibly. The act of translanguaging is expected to create a social space for multilingual speakers "by bringing together different dimensions of their personal history, experience and environment, their attitudes, beliefs and performance" (Wei, 2011: 1223). The languages are, thus, utilized flexibly and strategically so that classroom participants can experience and benefit from the permeability of learning across languages. Garcia and Wei (2014) define translanguaging as an approach to the use of language, bilingualism and the education of bilinguals that considers the language practices of bilinguals not as two autonomous language systems as has been traditionally the case, but as one linguistic repertoire with features that have been societally constructed as belonging to two separate languages.

Translanguaging pedagogy challenges what Cummins (2008) called the 'two solitudes' approach to bilingualism, in which languages were kept strictly separate. He argues that, translanguaging challenges monolingual assumptions that permeate current language education policy and instead treats bilingual discourse as the norm. According to Celic and Seltzer (2009), translanguaging refers to pedagogical practices that use bilingualism as resource, rather than ignore it or perceive it as a problem. Translanguaging as a theory intends to counter the widely held view that, the use of a first language in functioning in the L2 is a sign of lack of L2 proficiency thus it regards the use of an L1 as a resource for L2 learning and not as a weakness. In translanguaging the focus is not on L1 or L2 but on the language that is used by bilinguals in communicating a message. Translanguaging does not consider each language that is known to a bilingual as a separate entity but it considers those two languages as an internalised system that is used by a bilingual in communicating (Garcia and Wei, 2014). This research is therefore based on the fact that, bilingual education should not view L1 and L2 as separate. As Garcia (2009) has noted, bilingual education programmes that insist on two separate languages end up denying the complex multilingualism of much of the world. The L1 should be used as a resource in learning the L2. This theory is also suitable for this research since informal bilingualism is the pedagogy used by most teachers especially in most public schools and some have discovered that, it helps in the understanding of subject matter, thereby enhancing competence in learners.

\section{RESEARCH METHODOLOGY}

This study used the qualitative approach. Qualitative research involves direct experience during field work in order to be able to understand and interpret these tinges wellas the individuals (Creswell 2003). In qualitative research, the researcher is both the subject and the object of his research. According to Almeida et al (2017), the objective of the qualitative methodology is to produce in-depth and illustrative information in order to understand the various dimensions of the problem under analysis. The above authors also says that, qualitative research is therefore concerned with aspects of reality that cannot be quantified, focusing on the understanding and explanation of the dynamics of social relations. The population under study were all teachers from the selected schools, all learners from form 4 classes in the selected schools, all parents who have children at the selected schools and all government officials who are in charge of these schools. 
Sampling is a way of selecting a group from a population to represent a whole. According to Ogula, (2005) there are two sampling procedures which are probability and nonprobability sampling. This researchers used probability sampling where the chance of selecting each respondent is known or can be calculated. The study used purposive sampling under probability sampling. Patton (1990) says purposive sampling is a strategy in which particular settings, persons or events are deliberately the source. The schools, teachers, pupils, parents and education officers were purpose fully selected in order to obtain rich information about the influence of the LOI on students 'writing competence. Stratified random sampling was used topick students who were inter viewed in this study. In stratified random sampling, each entity is randomly selected from a population that has been divided into categories(Bryman,2008).The different classes and gender were considered during sampling, to avoid bias and had accurate presentation to ensure validity. The sample under study were 8 teachers, 4 from public schools and 4 from private schools, 40 learners from form 4 classes, 20 from public schools and 20 from private schools, 20 parents, 10 from two private schools and 10 from two government schools in Gweru Zimbabwe and 2 government officials who are in charge of these schools.

Bhattacharyya (2003) says that there are various ways that are used to gather data for use in a research project. One method of data collection for this study involved sending out questionnaires to the teachers and learners of the selected schools which were used for this research, parents with children at these schools and also government officials in the midlands province. The questionnaires were distributed to the sampled participants so that they could respond to them. These were later on collected by the researcher. Questionnaires were used because they were potentially useful, easy to use and were a reliable method of data collection. The fact that they are anonymous makes information collected to be authentic, people express their views clearly knowing that they are anonymous. The researchers also conducted interviews with 8 teachers, 20 learners, 2 government officials and 10 parents who were selected from the population. These were done in order to complement questionnaires. Interviews have the advantage that, they are supervised hence potentially prone to fewer difficulties (Chiromo 2006). Interviews also guarantee that it is the respondent alone who answers the questions. In addition to the two methods outlined above, the researchers also analysed pupils' 40 written documents, 20 from a public

ISSN: $2456-7620$

https://dx.doi.org/10.22161/ijels.53.26 schools and 20 from private schools. These were essays which were given to learners to write on the same topic from a past ZIMSEC examination question paper. The researchers analysed how the language of instruction affected the way learners write. Issues like syntax and semantics which include, sentence construction, paragraphing, spellings, use of colloquial language, use of parts of speech and also direct translation from mother tongue among other issues were analysed in order to assess the competence of the learners.

\section{RESULTS AND DISCUSSIONS}

Judging from the responses noted by the researchers, competent students from high density suburb government schools and most students from private schools preferred English as the medium of instruction, probably because, competent students have not much problems in using the English language and students from private schools have no option because English is the language in and outside the classroom and the medium of instruction whether they understand it or not. They also highlighted that, English is the official language of academics, business and communication and without it, one cannot progress academically or professionally, so it is important to learn using the language. A language of instruction is the language which is used by teachers and learners for teaching and learning. From the interviews that were held, the researchers asked the learners about the language which they preferred as the medium of instruction. There were various responses depending on the type of student and also the type of school where the student came from. These were some of the responses:

Learner 1:Our teachers always teach the English language in English because it makes us practice to use English properly and try to understand it better since it is the official language in Zimbabwe.

Learner 3: I think teachers should teach in English but when we do not understand, they should explain in Shona.

Learner 6: If teachers teach in English only, they talk themselves, we are silent because we can't understand them, so they have to speak in English then talk again in Shona.

Some high density urban secondary school learners pointed out that, there should be continuity in teaching using either the LOI; English, if it is a subject that has to be taught in English and indigenous languages in subjects requiring the 
use of Indigenous languages such as Shona or Ndebele; as students are reliant on code switching, code mixing and translations. She had to say this:

Learner 4: I think English should just be taught in English because even when we write our final exams, we will write them in English so we should get used. Indigenous languages should only be used when we are doing that particular subject.

However not- so competent learners from high density public schools preferred a mixture of English and indigenous languages. This could be probably because the teachers themselves were not proficient in English as mentioned by government officials in an interview; thus, students were not exposed to linguistic structures needed in academic discourse so their command of the language is very poor. Indigenous languages would therefore help them to get the meaning of what the teacher would be saying.

\section{Teachers' views on language of instruction}

Teachers also had different views concerning the language of instruction depending on the type of school they are working and also work experience. However from interviews with teachers it was clear that there is a relationship between language and achievement. One teacher from a private school said that, English should be taught in English because practice makes perfect. She said:

Learners should be taught English Language in English. This will help them to be competent as they practice using the language through listening to it, speaking it and reading it and also writing in it. The more they use the language, the more they become proficient in it.

However others preferred code switching, code mixing, direct translation and translanguaging in order to enhance meaning. One teacher from an urban high density suburb secondary school said:

Since English is a second language to most if not all of the students in these types of schools, it is only used in class and nowhere else so most of the not so competent students do not understand if you sorely teach in the English language. They will not participate in class discussions because they will not have heard anything. But if you explain or ask the same question in indigenous languages you see them raising their hands and giving good answers.

This shows that, code switching code mixing and translation helps learners to understand better.

Some teachers also said that, language of instruction determines whether examinations are passed or failed. They argue that, all tests and examinations are written in English. It would have been simpler if it was possible to answer exam questions in indigenous languages, but it is not allowed. In some occasions, students fail to express themselves fully and correctly, or are unable to correctly describe the answer, and such responses are not acknowledged, which makes them fail their examinations because they are regarded as incompetent. One teacher said;

English is a second language to most students and so when examination questions include vocabularies it's not easy for most students to understand the question(s). Thus, language could in a way contribute in their failure because of not understanding the exam question. If only they were allowed to answer in indigenous languages, I'm sure they would perform better, but unfortunately, that is not accepted.

The above sentiments shows that, language of instruction has a bearing on the competence of learners.

\section{Parents' views concerning language of instruction}

Parents however had different views from learners. They preferred that their children be taught in the English language since all other subjects are also taught in English except for indigenous languages. This would help the learners to understand other subjects as well, as they say. Parents also highlighted that, English helps learners to be able to communicate with other people who do not speak their language and is the language which is used in tertiary institutions and also in formal workplaces so they should be used to it. One parent said that,"a child who can speak and understand English language is very confident and can easily fit in any environment."

\section{Education officers' views}

In an interview with the education officer he said that, Indigenous languages should become the LOI in secondary schools and English should be taught as a compulsory subject because as he says, the decline in students' performance is because of English being the LOI. Education officer said that student's do not understand the examination questions because they are written in English. She said:

$$
\text { Ndinofunga kuti kudzidzisiwakunoita vana }
$$


nechirungundikokunoita kuti vasanyanyakupasa.

Hakusi kuti vana havanzwisisizvavanodzidziswaasi

kuti vazhinjivavohavanzwimubvunzo kana

ukabvunzwanechirungundizvozvinoita kuti

vasabudiriramuzvidzidzozvavo.

(I think that English as a LOI can be one of the factors contributing to the low achievement of students. It's not true that students don't understand what they are taught, but the main problem is that, they don't understand questions which are asked in English in the examination; that is what makes them fail.)

From the education officer's sentiments, it is clear that, students perform poorly in the English language because they do not understand examination questions which are asked in English. This means that, the use of a foreign language is the basis of this problem, which contributes to under-reaching among a large number of high school students. Another provincial educational officer said English as a subject should be enhanced by providing more oral exercises, additional reading, and textbooks because more reading increases knowledge and understanding. She also said that special English workshops should be held for the teachers to help them manage and develop English.

When she was asked about the issue of secondary school textbooks, she indicated that high-density urban schools have issues with book shortages because the syllabus has changed and the one currently in use requires new books that are still very few because some of them are still being published, because the old ones do not cover some of the new concepts in the syllabus. Even if we have some which are available they are not enough since students have to share because they are so many soit's not easy to buy book sat the same time. She said that in these schools, the problem is even worse because most of the students do not havethe culture of reading books. This is however different, in private schools because parents are either asked to buy books for their children and they do so because they can afford to, or the schools can buy the books even from outside the country because they have the money since they charge very high school fees. Therefore, in her opinion regular reading habits need to be promoted among the learners.

On the question of whether it is possible to change the LOI in the near future, she said it was important for the LOI to be changed from English to indigenous languages but the government and parents were unwilling to do so. One of the common reasons cited for the continued use of English as the LOI is globalization, meaning that Zimbabwe is not an island and the use of English as their communication medium helps to maintain diplomatic relations with other countries, as English is a global lingua franca. Furthermore, indigenous languages are not yet developed to express scientific and technical terms hence English remains the language of instruction.On this issue, the researchers suggest that the government through the ministry of education sport and culture should also facilitate professional training programs, workshops and seminars for teachers that will enhance teachers' language skills as well as pedagogy skills since they are also still trying to understand and comprehend the new curriculum. This will help the teachers to improve their English language competence and ensuring that high density suburb government secondary schools have adequate and well qualified teachers.

\section{Language used in and outside the classroom and at home}

Learners were also asked about the language which they use in class to converse either with their friends or with teachers and also the language which they use when they are at home. Almost all learners from high density secondary school said that, since their teachers use both languages to in the classroom, they also use both languages in class and their mother tongue outside the classroom and at home. They confessed that, even in the English lesson they might ask for permission from the teacher to explain a concept in their vernacular languages so that they are able to express themselves. Only one competent learner from high density suburb government school said that, he uses English every time, but was having a challenge of being laughed at by other students who think that he wants to be pompous. Some of the responses were that:

Learner 5: When we are in class or outside we use Shona everyone, it is easy to speak and our language. Even at home we speak Shona. I wish we were learning in class in Shona also.

Learner 6: I speak Shona and a few English in class but outside its Shona.

Learner 8: I always converse in English with my friend and even at home, I live with my brother and we speak English, but the problem is that people in class think that, I'm proud so they laugh at me and call me names .

However $95 \%$ of the students from private schools said that they communicate in English at home and at school, but 5\% 
mentioned that, they as friends they converse in their indigenous languages when they are alone and also at home. They are forced by the school policy to converse in English but they argue that, at times it is difficult to fully express yourself in English than in vernacular languages. These were some of the response from other learners:

Learner 1: I always speak in English whether I am at home or at school. Its now in my blood I have no problems speaking in English.

Learner 2: Yes I can speak in English but I enjoy using Shona when I am with my friends because I can express myself better in Shona than English. Even at home we speak Shona.

Learner 4: Here at school we are forced to speak in English, you go for punishment if you are found speaking in Shona but at home we use Shona, my parents do not want us to speak in English at home.

On another angle, there are different coping mechanisms that are used to allow teachers and students to complete the teaching and learning process such as code-switching, codemixing, translation and rote learning. Code-switching is defined as the alternate use of two or more languages in the same utterance, a common bilingual or multilingual communication strategy (Jacobson (1998). Code-mixing is the changing of one language to another within the same utterance or in the same oral/written text" (Ho, 2007: 1). Translation/ literal translation typically has been used to transfer written or spoken second language texts to equivalent written or spoken first language texts. OR the second language grammatical constructions are converted to their nearest first language equivalents, but the lexical words are again translated singly, out of context (Ordudari, 2007). Translanguaging however involves the use of indigenous languages as scaffold to understanding English. These teachers argue that, these strategies helps especially in acquiring meaning. The findings reveal that, students from urban high density secondary school said they regularly used code switching and code mixing in group discussions in the classroom to help those who don't understand English contribute their views. This was supported by one student who said;

Another high density secondary school student also stated another coping strategy that students usually use. This is memorization of the main themes and reproducing them in examinations. She said:

ISSN: $2456-7620$

https://dx.doi.org/10.22161/ijels.53.26
Kana mudzidzisi akadzidzisa nechirungu, isu tinoranda mapoints akakosha chete tozoanyora sezvaari mиехат. Dambudziko rinovapo nderekuti hatizogoni kutsanangura mapoints acho nokuti anenenge ataurwa nechirungu.

(When a teacher teaches in English we memorize the main points and then we repeat exactly what we memorized in the examination. The problem is that we fail to explain the details of each point mentioned because one may not have understood what was said since it was said in English).

One of the students from the high density urban secondary schools suggested peer teaching as one way to help the students who are unable to cope with the language of instruction:

Zviri nyore kuti isu pachedu sevana
tidzidzisane nokubvunzana
zvatisinganzwisisi panekuti tibvunze
vadzidzisi nokuti hatina kunyatso
sununguka kuvabvunza, saka ivo
vanofanirwa kutikurudzira kuti isu
tidzidzisane tichibatsirana.

(It is easier to ask each other questions as students rather than asking the teachers, because we are not very comfortable asking them, so teachers should encourage peer teaching so that we can help each other).

It means peer tutoring could be used as a coping strategy for students to help each other to understand what was taught in the classroom; those who are competent in the language of instruction to assist those who are not so competent.The coping strategies used are necessary to enable learners to understand, but some of the techniques may not be particularly useful in memorizing, referred to as rote learning. When students are unable to describe what they have memorized, which means they have not grasped what they have learned and therefore are not competent in the language of instruction.

However there are also other strategies which are employed by both competent and not so competent learners. These include, taking notes, seeking for clarification from teachers on concepts not understood, group discussion, role play, 
making corrections to rectify mistakes on written essays, revising work learnt in class, writing extra essays and giving them out for marking, reading widely other materials in English for example newspapers, story books and making summary notes on the set texts for essay writing, proof reading written essays and also, planning or organizing ideas before writing among other strategies. Although the Zimbabwean government has made an effort to source English language books through UNICEF, the books are still not enough especially in high density government schools, so there is need to consider supplying secondary schools with adequate teaching and learning material so that learning can be made easier and also equip libraries which are in the schools with relevant and current books in order to help learners develop a culture of reading. Since English is currently the official language of instruction, more effort should be placed to improve the quality of English language. Practical measures need to be taken by the government to ensure that the teaching and learning of English language is enhanced in order to improve students"e academic achievement. In future the Zimbabwean government, through the ministry of education sports and culture should consider including a language option in writing examinations. In other words, students should be given the option of writing exams in either English or their mother tongue. Probably this might help students to perform better in their examinations. The government through the ministry of education sport and culture should also give importance to all subjects including English not only science subjects which they are sponsored through STEM program, when providing financial resources in secondary schools.High density secondary schools should encourage their learners to use English as a language of communication in and outside the classroom so as to make them use the language frequently. They should also develop in their learners a culture of reading by slotting library periods on their time tables and encouraging learners to read other materials such as novels, newspapers or magazines, besides their school books.

\section{CONCLUSION}

This research examined the impact of language of instruction on students ' academic performance in high density urban secondary schools and private secondary schools and concluded that, language of instruction has a major influence on learners ' academic achievement. While most teachers have a good command in the language of instruction, they have to use coping strategies such as codeswitching and translation to help students understand the lesson properly.Coping strategies are useful in helping students understand the subject matter; however, they are not the most effective means of achieving the process of teaching and learning as the result leads to poor performance. The main problem is that exams are written in English and techniques like code switching, code mixing and translation are illegalso they cannot be used and this leads to failure.The most effective coping strategy is peer tutoring that helps less able students gain a better understanding of a subject and ultimately become confident and autonomous in other challenging tasks.Learners from high density secondary schools use both English and indigenous languages to communicate in and outside the classroom and at home also, since their teachers do so as well, however learners from private schools always converse in English.Due to the wording of the questions and the difficult vocabularies used, the examination questions were seen as an obstacle. Therefore, students are unable to fully understand the exam questions, and are unable to provide accurate answers. Even when they try to answer their answers in writing they are unintelligible or poorly expressed.

\section{ACKNOWLEDGEMENTS}

We feel greatly indebted to the following academics; Mugomba M, Njanji T, Mawire P, Matandare S. and Mutema F.who took their precious time to give precious contributions for the study.You created a stimulating environment, which helped immensely in generating some of the ideas and observations in this study. Your views were very informative to our study and research endeavours.

To the students and teachersin the private and publicsecondary schools in Gweru we say thank you so much for sparing your time for our study; answering the questionnaires and interview questions. We are grateful for all the support you gave. You provided valuable research materials and interviews for this study.

We wish to thank all my colleagues in the Communication Skills Centre at the Midlands State University for their participation, keen interest and zeal for this study. Your imperious guidance and encouragement cannot be forgotten, you have been instrumental! 
[1] Ahmed, A. 2010.Students' problems with cohesion and coherence in EFL essay writing in Egypt: Different perspectives. Literacy Information and Computer Education Journal (LICEJ), Vol.1, 219-221.

[2] Almeida, F., Faria, D and Queiros, A.2017.Strengths and Limitations of Qualitative and Quantitative Research Methods, European Journal of Education Studies, 3(9) 369386.

[3] Bilal, H. A., Tariq, A. R., Din, N., Latif, H., and Anjum, M. N. 2013. Investigating the problems faced by the teachers in developing English writing skills. Asian Journal of Social Sciences and Humanities, 2(3), 238-244.

[4] Bhattacharyya D.K 2003.Research Methodology, 1sted, New Delhi: ExcelBook

[5] Bryman, A.2008.Social ResearchMethods. ( $3^{\text {rd }}$ Ed) NewYork: Oxford University Press.

[6] Brock-Utne, B. 2004. English as the language of instruction or destruction - how do teachers and students in Tanzania cope? In Brock-Utne, Birgit, Zubeida Desai \& Martha Quorro (Eds). Researching the language of instruction in Tanzania and South Africa. Cape Town: African Minds.

[7] Canagarajah,S. 2011.Translanguaging in the Classroom: Emerging Issues for Research and Pedagogy,Applied Linguistics Review 2, 1-28.

[8] Celic, C. and Seltzer K. 2009. Translanguaging: A CUNYNYSIEB guide for educators. New York: CUNY-NYSIEB, The Graduate Centre, The City University of New York. Retrieved from: http://www.nysieb.ws.gc.cuny.edu/files/2013/03/Translangua ging-Guide-March-2013.pdf

[9] Cenoz, J and Gorter, D. 2011. A Holistic Approach to Multilingual Education,Introduction to Modern Language Journal, 95, 339-343

[10] Chiromo, A.S. 2006. Research Methods and Statistics in Education. A Student's Guide. Gweru. Beta Print.

[11] Chomsky, N. 1965. Aspects of the Theory of Syntax. Cambridge, MA: MIT Pres

[12] Cohen, L., Manion, L. and Morrison, K. 2000. Research Methods in Education. London: Routledge.

[13] Cole, J. and Feng, J. 2015. Effective strategies for improving writing skills of elementary English language learners. Chinese American Educational Research and Development Association Annual Conference, April 15-16, 2015 in Chicago, IL

[14] Creese, A. and Blackledge, A.2010. Translanguaging in the Bilingual Classroom: A Pedagogy for Learning and Teaching? Modern Language Journal 94(1), 103-115.

[15] Creswell, J. W. 2003. Research design: Qualitative, quantitative, and mixed methods approaches (2nd Ed.) Thousand Oaks, CA: Sage.

[16] Cummins, J 2008. Teaching for Transfer: Challenging the two solitudes assumption in bilingual education. In: Jim Cummins and Nancy H. Hornberger (Eds). Encyclopedia of Language and Education Vol. 5: Bilingual Education (2nd edition edition). Boston: Springer Science + Business Media.

[17] Ellis, R. 2003.Task-based language learning and teaching. Oxford: Oxford University Press.

[18] Fairclough, N.and Wodak,R1997. "Critical discourse Analysis" in T.A Van Dijk (Ed) Discourse Studies, a multidisciplinary interaction,London: Sage.

[19] García, O. 2009. Bilingual education in the 21st century: A global perspective. Malden, MA and Oxford, England: Blackwell/Wiley.

[20] Garcia, O. and Sylvan, C.E. 2011. Pedagogies and practices in multilingual classrooms: Singularities in pluralities.The Modern Language Journal, 95, 385-400

[21] García, O, and Wei, L. 2014.Translanguaging: Language, Bilingualism and Education.Basingstoke: Palgrave Macmillan.

[22] Gonye, J., Mareva, R., Dudu, W. T. and Sib, J. 2012. Academic writing challenges at universities in Zimbabwe: A case study of Great Zimbabwe University. International Journal of English and Literature,3(3), 71-83.

[23] Graham, S., and Perin, D. 2007.A Meta-analysis of writing instruction for adolescent students. Journal of education research, Vol. 99,445-476.

[24] Haider, G. 2012. An insight into difficulties faced by Pakistani student writers: Implications for teaching of writing.Journal of Educational and Social Research,2(3), 17-27.

[25] Ho, J. W. Y. 2007. Code-mixing: linguistic form and sociocultural meaning. International Journal of Language, Society and Culture, (21), 23-30.

[26] Jacobson, R. 1998. Codeswitching Worldwide. Berlin/New York: Mouton de Gruyter.

[27] Kagwesage, A. M. 2012. Higher education students' reflection on learning in times of academic language shift,International Journal for the Scholarship of Teaching and Learning, 6(2), $1-15$.

[28] Kroll, B. 2003.Exploring the dynamic of second language writing. New York: Cup.

[29] Komba, S. C and Bosco, S. 2015. Do Students' Backgrounds in the Language of Instruction Influence Secondary School Academic Performance?Journal of Education and Practice, 6(30), 148-156.

[30] Lewis, G., Jones,B.and Baker, C.2012.Translanguaging: origins and development from school to street and beyond. Educational Research and Evaluation: An International Journal on Theory and Practice, 18(7), 641-654.

[31] McGroarty, M. (1996). Language Attitudes, Motivation, and Standards. In S. L. McKay, \& N. Hornberger (Eds), Sociolinguistics and Language Teaching. Cambridge: Cambridge University Press.

[32] McGroarty, M. (1996). Language Attitudes, Motivation, and Standards. In S. L. McKay, \& N. Hornberger (Eds), Sociolinguistics and Language Teaching. Cambridge: Cambridge University Press. 
[33] McGroarty, M. (1996). Language Attitudes, Motivation, and Standards. In S. L. McKay, \& N. Hornberger (Eds), Sociolinguistics and Language Teaching. Cambridge: Cambridge University Pres

[34] McGroarty, M. (1996). Language Attitudes, Motivation, and Standards. In S. L. McKay, \& N. Hornberger (Eds), Sociolinguistics and Language Teaching. Cambridge: Cambridge University Pres

[35] McGroarty, M. 1996. Language attitudes, motivation and standards. In McKay, S. and Hornberger, $\mathrm{N}$ (Eds) Sociolinguistics and Language Teaching, New York: Cambridge University Press.

[36] Mlay, N. 2010. The influence of the language of instruction on students' academic performance in secondary schools: a comparative study of urban and rural schools in ArushaTanzania. Unpublished Masters' degree in Comparative and International Education. University of Oslo: Norway.

[37] Myles, J. 2002. Second language writing and research: The writing process and error analysis in student texts. Teaching English as a second or foreign language Journal, 6(2) 1-19.

[38] Negari, G.M. 2011. A study on strategy instruction EFL learners' writing. International journal of English linguistics, 1 (2), 299-307.

[39] O‘Malley, J.M. and Chamot, A.1990. Learning strategies in second language acquisition. Cambridge: Cambridge University Press.

[40] Ordudari, M. 2007. Translation Procedures, Strategies and Methods. Translation Journal Vol.11 (3), [http://accurapid.com/journal/19/culture2htm].

[41] Ogula, P. A. 2005. Research Methods. Nairobi: CUEA Publications.

[42] Ong'ondo C. 2001. KCSE writing skills. Nairobi: World Link Press Publishers.

[43] Patton, M.Q. 2005.Qualitative evaluation and research methods, Thousand Oak C A:Sage.

[44] Pineteh, E. A. 2013. The academic writing challenges of undergraduate students: A South African case study.International Journal of Higher Education,3(1), 12.

[45] Quintero, L. M. 2008. Blogging: A way to foster EFL writing.Colombian Applied Linguistics Journal, 10(1), 7-49.

[46] Rao.Z. 2007.Training in brainstorming and developing writing skills. ETL Journal, 61(2), 44-51.

[47] Rahman, T. 2002. Language, ideology and power, Oxford: Oxford University Press

[48] Van Dijk, T. A (1989) Critical Discourse Analysis. Available at http://www.hum.uva.ni/teun/cda.htm.

[49] Wei, L 2011. Moment Analysis and Translanguaging Space: Discursive Construction of Identities by multilingual Chinese Youth in Britain. Journal of Pragmatics, Vol 43, 1222- 1235.

[50] Williams, C. 1994. Arfarniad o ddulliau dysgu ac addysgu yng nghyd-destun addysg uwchraddddwyieithog [An evaluation of teaching and learning methods in the context of bilingual secondary education] (Unpublished $\mathrm{PhD}$ thesis). University of Wales, Bangor, UK 